\title{
Characteristics Effects of Weed on Growth Performance and Yield of Maize (Zea Mays)
}

\author{
Abdulraheem Mukhtar Iderawumi*1 and Charles Eneminyene Friday ${ }^{2}$ \\ ${ }^{1}$ Department of Agricultural Science Education, The College of Education, Nigeria \\ ${ }^{2}$ Nigeria Institute for Oil Palm Research, Nigeria
}

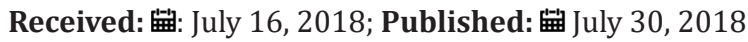

*Corresponding author: Abdulraheem Mukhtar Iderawumi, Department of Agricultural Science Education, The College of Education, P.M.B. 001, Lanlate, Oyo State, Nigeria.

\begin{abstract}
Maize (Zea mays), which is the third most important cereal crop of the world, is an important dual purpose crop used in human diet and animal feed. The experiment was conducted to investigate the effect of weeds on the growth and yield of maize, and to determine the best time and frequency of weeding to get an optimum yield. The experiment was conducted at Teaching and Research Farm of The College of Education, Lanlate in the cropping season of 2016. There were four treatments replicated four times to make the total number of plot to be sixteen (16). The treatments are; No weeding, weeding after 2, 3 and 4 weeks. It was shown that if the first weeding is done between 3weeks and 2 weeks after planting the optimum yield will be obtained. When the first weeding is allowed to reach 4weeks before it is done there is a drastically reduction in the crop. A crop failure with absolutely low yield was obtained in a field where weeding was not done at all.
\end{abstract}

Keywords: Maize; Weed; Yield; Growth

\section{Introduction}

Several million people in the developing world consume maize as an important staple food and derive their protein and calories requirements from it. Maize is thus a potential source of protein for humans and animals. It holds a great promise for increasing production and also as a future protein crop [1]. Maize (Zea mays L) is a member of the family Graminae and it is an annual crop serving as a good source of food for human consumption in form of maize powder, maize meal and confectionaries such as bread, biscuits and cakes. Maize is world's one of the three most popular cereal crops. It is grown is worldwide on approximately 130 million ha annually with a production of 574 million metric tons [2]. It occupies an important position in world economy and trade as a food, feed and an industrial grain crop. Several million people in the developing world consume maize as an important staple food and derive their protein and calories requirements from it.

Maize is essentially an important component of the farming systems and the diet of many people in the tropics and can be processed into different products for various end uses both at the traditional level and industrial scale, though a large production of products utilized in developing countries is obtained via traditional processing while industrial processing meets the bulk of the demand in developed countries [3]. Ogieva [4]. Maize is the most highly distributed cereal in the World used for human and animal feeds as well industrial purposes [3]. The demand for maize is always higher than what is being produced in the country.
For instance in the year 2005, over 4.0 million tons of maize was imported from Lebanon, Italy, Belgium and Indian NBS [5] and about 1.772 billion Naira worth of maize was imported in 2006 NBS $[6,7]$ identified industrial use of maize for making corn oil, starch, cornflake, glucose and alcohol. It can also be used as a components of livestock feed, for making corn meal, beer and baking flour.

The major environmental problems associated with the cultivation of maize, according to Silva [8] is the temperature as it affects directly the growth and distribution of the plant. Auld [9] also stated wind as an environmental problem as it affects the level of rainfall and causes serious damage to the crop inform of lodging while too much of rainfall can lead to erosion. Biotic factors such as parasites, weeds, pests and diseases and soil organisms reduce the income of the farmers. Weed is a man made problem, though disturbance of ecology where undesirable plant emerge. Weeds may be regarded as any plant or vegetation except fungi that interferes with mans objectives. They are unwanted biological are exclusively associated with man and his activities. Weeding accounted for a major part of farming activities and so are were worried that developing an effective method of weed control, weeding less human effort /labour would lead to employment. Weeds science started as weeds control strategies rather than understanding of weeds in relation to the ecosystem and how weeds affect crops. There are recent advocate for development of weeds managements with takes roots from its parents basis science 
especial biology. This will lead to a combination of methods. like biology, chemical, physical and preventive methods.

\section{Significance of Weed}

a) Reduction in Crop Yield: Through their competition with crop for light, nutrient, water and sometimes space. They also produce chemicals that are harmful to the growth of associated crops (allelopatic effect), serve as alternative host to pest and disease of crop plant. Water leaf (Talinum triangulae and tridax procumbens) is known to serve as host plant for root-knot nematodes.

b) Reduction in Crop Quality: The mixture of weed seed and crop produce usually reduces their quality grades and market value (price) that are offered for such product e.g. cocoa grade $1: 2: 3$.

c) Reduction in animal's Product Quality: Some weeds are poisonous to grazing animals, Amaranthus spinosus at its earlier stage, wild onion (garlic) is known to cause unacceptable flavour in milk. The quality of wool of animal is equally reduced by weed especially those with hooks.

d) Some Weeds have Poisonous Effects: Posing danger to crop yield, increase cost of production (cost/unit) e.g. cost of weeding.

e) Weed, a Threat to Water Bodies: Fishing, irrigation and navigation can be hampered by weeds. For instance, water hyacinth, Eichhornia crassipes is a menace to water bodies; water lettuce, pistia stratiotes affects navigation as well as reducing pond volume. They could be suspended in pipe for irrigation.

\section{f) Beneficial Effects:}

a) Help control erosion in uncultivated land having fibrous roots to bind the soil particle together.

b) Establish a soil cover that shield the soil from harsh environmental factors of high isolation, torrential rainfall.

c) Serve as source of organic matter to soil.

d) Help to reduce leaching of mobile nutrients like nitrates through the process of nutrient recycling.

e) Source of heir genes in plant improvement.

f) As herbage for livestock.

g) Shelter for wild life.

h) Source of pesticide.

i) consumed as talinum.

Iwena [10] emphasized on weeds as limitation to maize production as they compete with crops for space and nutrients, especially when the weeds are rapidly crowded. Weeds habour maize pests and diseases by acting as hosts and this indirectly reduce the quality of the harvested maize and the market value [11] asserted that the low yield as a result of weeds infestation coupled with the reduction in the quality of maize produced and increase in the cost of controlling the weeds consequently lead to loses or reduction in the income of the farmers.

\section{Weed Control Methods}

a) Weed prevention: Prevention is methods taken to avert the establishment of new species with area where their species does not occur. Prevention is achieved primarily through law enacted by government.

b) Eradication: Means that a given weed species, its seed and vegetative propagule had been killed and completely removed from a given area and that the weed will not appear unless it is re-introduced. This is almost impossible; it can only be achieved on a small area of land.

c) Control: Implies methods which are used to keep weeds away from a piece of land at a given time. Management is related to control but in management weeds are not kept away but suppressed to a level where crops thrive without the effects of the weeds using a combination of methods. Methods of control can be placed under these headings; Cultural, Biological, Mechanical and Chemical.

Iwena [10] also reported various methods of controlling weeds on maize plantation which include the use of physical control, chemical control, mechanical control and biological control. The physical control involves the use of hand, cutlasses and hoes to clear the weeds. Mechanical control of weed involve of mower, cultivator which are pulled by tractors to clear the weeds from the farm land and this saves time and energy and makes the work easy. However, the use of machine/tractor to control the weeds is by the farmers is unrealistic as many of them have no access to this facility. Similarly, the use of biological control which involves the introduction of some insect and herbivorous animals to farmland to eat up the weeds is also cumbersome and unrealizable because the useful crops may also be eaten up along with the weeds. Therefore, the aim of this study is to determine the effect of weed infestation on the growth and development of maize; to evaluates the yield of maize at different weed density and to investigates the threshold (critical period) above which weed infestation becomes detrimental to the yield of maize.

\section{Materials and Methods}

Experiments was conducted at the Teaching and Research Farm of The College of Education, Lanlate, Southwest, Nigeria in 2018 cropping seasons to study the effects the effect of different time of weeding on the growth and yield of maize. Lanlate lies between latitude $7030^{\prime} \mathrm{N}$ and Longitude 30 52' $\mathrm{E}$ in the tropical rainforest belt f Nigeria. There are two rainy seasons; one from April to July (early season) and the other from mid-August to November (late season). Annual average minimum and maximum temperatures are $24.800 \mathrm{C}$ and $28.100 \mathrm{C}$ respectively. The mean relative humidity is about $75 \%$. The soil at the site is classified as an alfisol (Oxic tropuldalf) according to Adeputu [12]. There were four treatments replicated four times in a Randomized Complete Block Design. The treatments were namely; The Control (no weeding), weeding at 2 weeks after 
planting; weeding at 3 weeks after planting and weeding at 4 weeks after planting. Each of the 16 plots was $4 \mathrm{~m}$ by $4 \mathrm{~m}(16 \mathrm{~m} 2)$ in size and seeds were planted at $0.60 \mathrm{~m} \mathrm{X} 0.30 \mathrm{~m}$. Plant growth and yield parameters taken includes plant height, stem girth, number of grain as well as grain weight per cob. Data were analysed using Analysis of Variance (ANOVA) to determine the effects of treatments on the parameters measured. Duncan Multiple Range Test was used to compare the treatment means.

\section{Results}

Table 1 shows the pre-planting soil analysis. It was loamy sand with a pH (H2O) of 6.6, total N 0.09\%, available P $5.6 \mathrm{mg} /$ $\mathrm{kg}$, organic C $1.73 \%$, organic matter (OM) 2.62\%. The respective values for exchangeable $\mathrm{K}, \mathrm{Ca}, \mathrm{Mg}$ and Na were $0.25,2.6,2.1$ and $0.18 \mathrm{cmol} / \mathrm{kg}$. The OM falls within $0.5-4.0 \%$ established for soils of southwestern Nigerian Adepetu and Corey, but lower than critical level of $3 \%$ specified by Akinrinde \& Obigbesan [13]. The total $\mathrm{N}$, available $\mathrm{P}$ and exchangeable Ca fell below critical level levels of $0.15 \% \mathrm{~N}, 10.0 \mathrm{mg} / \mathrm{kg}$ available $\mathrm{P}, 2.0 \mathrm{cmol} / \mathrm{kg}$ exchangeable Ca and $0.4 \mathrm{cmol} / \mathrm{kg}$ established for crop production in southwestern Nigeria by Akinrinde \& Obigbesan [13]. Therefore, response to the applied fertilizers is expected (Tables $1 \& 2$ ).

Table 1: Initial soil analysis of experimental site at Lanlate.

\begin{tabular}{|c|c|}
\hline Properties & Values \\
\hline $\mathrm{pH}\left(\mathrm{H}_{2} \mathrm{O}\right)$ & 6.50 \\
\hline Organic Matter (\%) & 2.62 \\
\hline Total Nitrogen $(\mathrm{N}) \mathrm{g} / \mathrm{kg}$ & 0.09 \\
\hline Available Phosphorous $(\mathrm{P})(\mathrm{mg} / \mathrm{kg})$ & 5.60 \\
\hline Exchangeable Calcium $(\mathrm{cmol} / \mathrm{kg})$ & 2.60 \\
\hline Exchangeable Magnesium $(\mathrm{Mg})(\mathrm{cmol} / \mathrm{kg})$ & 2.10 \\
\hline Exchangeable Sodium $(\mathrm{Na})(\mathrm{cmol} / \mathrm{kg})$ & 0.18 \\
\hline Exchangeable Potassium $(\mathrm{K})(\mathrm{cmol} / \mathrm{kg})$ & 0.25 \\
\hline Sand $(\%)$ & 81.20 \\
\hline Silt $(\%)$ & 5.60 \\
\hline Clay $(\%)$ & 13.20 \\
\hline Texture & Loamy sand \\
\hline
\end{tabular}

Table 2: Effects of Weed on Growth parameters of Maize.

\begin{tabular}{|c|c|c|}
\hline Treatment & Plant height $\mathbf{( c m})$ & Stem Girth \\
\hline Control & $53.9 \mathrm{c}$ & $3.35 \mathrm{~b}$ \\
\hline $2 \mathrm{WAP}$ & $141.0 \mathrm{a}$ & $9.40 \mathrm{a}$ \\
\hline $3 \mathrm{WAP}$ & $143.5 \mathrm{a}$ & $9.65 \mathrm{a}$ \\
\hline $4 \mathrm{WAP}$ & $101.25 \mathrm{~b}$ & $3.35 \mathrm{c}$ \\
\hline
\end{tabular}

Note: Means followed by the same letter with in each column are not significantly different $(\mathrm{P}=0.05)$ as indicated by Duncan's Multiple Range Test.

The table above shows the average plant height with $143.5 \mathrm{~cm}$ for 3WAP where the plant is weeding 3 weeks after planting, followed by $141 \mathrm{~cm}$ for 2 WAP where weeding takes place 2 weeks after planting, followed by $101.25 \mathrm{~cm}$ for 4 WAP where weeding takes 4 weeks after planting. The least plant height was $53.9 \mathrm{~cm}$ for control where there was no weeding through out the period. The minimum average plant girth was $9.65 \mathrm{~cm}$ for $3 \mathrm{WAP}$ where weeding takes place 3 weeks after planting, followed by $9.4 \mathrm{~cm}$ for 2 WAP where weeding takes place 2 weeks after planting, followed by 4.35 for 4WAP where weeding take place 4weeks after planting (Table $3)$. The average weight of 100 grains was highest with $222.5 \mathrm{~g}$ for 3WAP where the weeding was done 3 weeks after planting, followed by $200 \mathrm{~g}$ for 2 WAP weeding after planting, followed by $110 \mathrm{~g}$ for 4WAP where weeding takes 4 weeks after planting. The least weight of 100 grains was recorded for $51.1 \mathrm{~g}$ where weeding was not done at all. The highest number of grains per cob is 595 grains for 3WAP, followed by 2WAP with 480 grains, followed by 4 WAP with 470 grains. The least number of grains per cob is 133 grains for control where weeding was not done at all.

Table 3: Effects of Weed on Growth parameters of Maize.

\begin{tabular}{|c|c|c|}
\hline Block & Weight of $\mathbf{1 0 0}$ grains $\mathbf{( g )}$ & No of cob per treatment \\
\hline Control & $51.5 \mathrm{c}$ & 133 \\
\hline $2 \mathrm{WAP}$ & $200 \mathrm{a}$ & 480 \\
\hline $3 \mathrm{WAP}$ & $222.5 \mathrm{a}$ & 470 \\
\hline $4 \mathrm{WAP}$ & $110 \mathrm{~b}$ & 133 \\
\hline
\end{tabular}

Note: Means followed by the same letter with in each column are not significantly different $(\mathrm{P}=0.05)$ as indicated by Duncan's Multiple Range Test.

\section{Discussion}

The results for the plant height and plant girth were used to evaluate the growth performance of maize plant for each treatment. The result shows that the growth performance of the maize was at peak for 3WAP and 2WAP which their first weeding started 3 weeks and 2 weeks after planting respectively. Smith, et. al. [14] reported that, of the four groups of agricultural production hazards namely. Diseases, Insect pests, Rodents/Predatory animals and Weeds, weeds have been found to cause the greatest losses in crop production. Adigun [15] also reported $87 \%$ and $90 \%$ losses in chilli pepper fruit yield due to season - long weed infestation during the wet season and dry season respectively. A yield reduction of $50 \%$ in potato was recorded in a weed interference study [16]. The result also showed that the growth performance of the maize was reduced significantly when the weeding was delayed till 4 weeks after planting for 4 WAP. The growth performance for control where weeding was not done at all was exceedingly poorer where the plants were stunted and thin. This was ascertained by Adejonwo et al. [17] 1989 earlier work that uncontrolled weed growth throughout the crop's life cycle reduced okra fruit yield by $88 \%$ in 1984 and $90 \%$ in 1985 at Kadawa near Kano compared with those kept weed free throughout the growth period.

In order to evaluate the yield of the maize plant for each treatment, weight of 100 grains per cob and number of grains per cob for each treatment were used. The result showed that the maximum yield (highest number of grains/cob and weight of 100grains) were recorded for 3WAP and 2WAP where the first weeding done 2 weeks and 3 weeks after planting of maize respectively. The yield for 4WAP where the first weeding was done 4weeks after planting was drastically and significantly reduced. The experiment has showed that weeding is very essential in the cultivation $\mathrm{f}$ maize for the good performance and yield of crop. If a 
good yield of maize will be obtained, it is recommended that the first weeding should be done not later than 3 weeks after planting. If the first weeding is delayed up to 4 weeks before it is done a significant reduction in the growth performance and yield of the crop will be obtained. However if no weeding is done it will result to almost a total crop failure where absolutely no yield will be obtained.

\section{Conclusion}

With the harmful effects of weeds in maize crop production, it becomes imperative to control them adequately and timely for maximum benefits. And this can be affected by adopting the preventive, cultural, biological, chemical and integrated weed control methods. However, to enhance the good quality of maize produce, there must be good farm sanitation through regular and timely control of weeds, use of resistant or tolerant crop varieties, timely planting, availability of suitable type of soil, soil sterilization, accessibility of market and transport facilities and availability of all - the- year - round water supply. Soil analysis must be carried out to determine the soil $\mathrm{pH}$ while pests and diseases should also be controlled. Therefore, it is advisable for the farmers or the growers of maize to do their first weeding 2-3weeks after planting in order to get optimum yield.

\section{References}

1. Abdulraheem MI, Ojeniyi SO, Charles EF (2012) Effect of Different Planting Pattern on Total Dry Matter Production and Maize Forage Quality in Maize (Zea Mays) and Cowpea (Vigna Sinensis) Intercropped as Whole-Crop Forage. International Organization of Scientific ResearchJournal of Agriculture and Veterinary science (IOSR-JAVS) 1(4): 42-46.

2. ItoS (1998) General Overview on Exploding Maize Demand in Asia International Maize.

3. Abdulraheem MI, Charles EF (2013) Effects of Geometric row Arrangement on Growth and Yield of Cowpea in a Maize- Cowpea Intercrop. Indian Journal of Innovations and Developments, Indian Society for Education and Environment (ISEE) 2(1): 816-820.

\section{ISSN: 2574-1241}

DOI: $10.26717 / B J S T R .2018 .07 .001495$

Abdulraheem Mukhtar Iderawumi. Biomed J Sci \& Tech Res

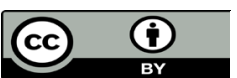

This work is licensed under Creative Commons Attribution 4.0 License

Submission Link: https://biomedres.us/submit-manuscript.php
4. Ogieva Erebo (1998) Comprehensive Agricultural Science for Senior Secondary Schools and Colleges. pp. 159.

5. Garki Abuja (2005) National Bureau of Statistics (NBS).

6. Garki Abuja (2006) National Bureau of Statistics (NBS).

7. Wilson BJ (1990) Morphology and yield response to weed pressure by corn hybrid differing in canopy architecture. Europ J Agron 14(4): 293302.

8. Silva K (1994) Weed control in grain corn. weed science 5: 121-241.

9. Auld BA (1998) Understanding Maize-Weed competition Resource competition, Light quality and the whole plant. Field crop pest 71(2): 139-150.

10. Iwena OA (2000) Essential Agricultural Science for Senior Secondary Schools pp. 151-159.

11. Teasdole JR (1993) A model concerning to the yield loss of maize. Density J 86(3): 401-500.

12. Adeputu JA, Adebayo AA, Aduayi EA, Alofe CO (1979) Preliminary survey of the fertility status of soils in Ondo State under traditional cultivation. Ife Journal of Agriculture 1: 134-139.

13. Akinrinde EA, Obigbesan GO (2000) Evaluation of the Fertility Status of Selected Soils for Crop Production in five Ecological Zones of Nigeria. Proceedings of the 26th Annual Conference of Soil Science Society of Nigeria pp. 279-288.

14. Smith MAK, Owolafe OA, Owanikin AK (200I) Effect of poultry manure on weed growth and yield of Indian spinach (Basel/a alba L.) in a humid tropical environment.

15. Adigun JA (1984) Effects of period of weed interference. Weed control on rainfed and irrigated pepper (Capsicum spp) p. 143.

16. Nwokoclia HN (1983) Weed interference studies in potato Annual Report. National root Crops Research Institute pp. 88-93.

17. Adejonwo KO, Ahmed MK, Lagoke STO, Karikari (1989) Effect of variety Nitrogen and period of weed interference on growth of okra (Abelmoschm esculentus). Nigeria Journal of Weed Science 2: 21-27.

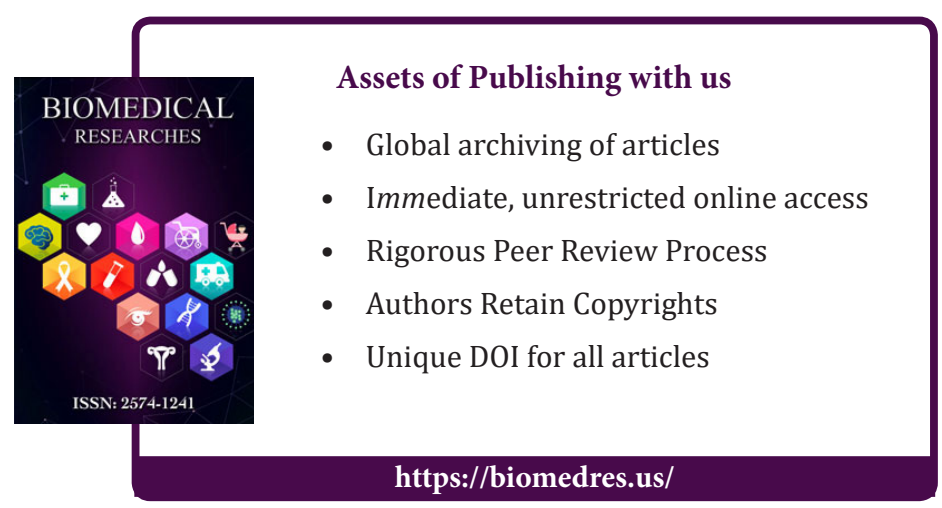

